\title{
PENGEMBANGAN KOMPETENSI PEMASARAN PADA DESA WISATA KAMPUNG BAMBU BANYURESMI PANDEGLANG
}

\author{
Diqbal Satyanegara1, Widya Nur Bhakti Pertiwi², dan Fadhilah ${ }^{3}$ \\ ${ }^{1}$ Program Studi D3 Manajemen Pemasaran, Universitas Sultan Ageng Tirtayasa, Serang \\ Email: diqbal.s@untirta.ac.id \\ ${ }^{2}$ Program Studi D3 Manajemen Pemasaran, Universitas Sultan Ageng Tirtayasa, Serang \\ ${ }^{3}$ Program Studi D3 Manajemen Pemasaran, Universitas Sultan Ageng Tirtayasa, Serang
}

\begin{abstract}
Local tourism become one of the important sectors that need to be attent by higher education institution through community service activity in order to has ability to compete in the ASEAN Economic Community (AEC). Desa Wisata Kampung Bambu (DWKB) is one of tourism villages located in Banten managed by people of the village in a group called Kelompok Sadar Wisata (Pokdarwis). In correlating with the conditions of the AEC and it local potential, the development of work competencies according with Standar Kualifikasi Kerja Nasional Indonesia (SKKNI) has become important for the business, including Pokdarwis DWKB so that they can understand about work competencies in marketing. Therefore, they can promote their own village precisely and directly based on the implementation of their marketing performance. The target of this program is that Pokdarwis is able to plan sales activities, approach potential customers, carry out effective communication, and identify DWKB marketing elements. The program method is by provide training in preparing sales activity plans, approaching potential customers, implementing effective communication, and identifying DWKB marketing elements. Based on the competency test simulation carried out after providing an understanding of marketing competence, the conclusion is that, Pokdarwis has not fully understood and mastered marketing competencies and there are still several marketing competencies that need to be explained more such as aspects of sales planning, communication, determining the marketing mix, and how to approach the customers.
\end{abstract}

Keywords: Marketing Competency, Tourism Village, Pokdarwis

\begin{abstract}
ABSTRAK
Pariwisata lokal menjadi salah satu sektor penting yang perlu menjadi perhatian lembaga pendidikan tinggi melalui pemberdayaan dan pengabdian masyarakat. Hal ini bertujuan agar sektor ini mampu berdaya saing dalam Masyarakat Ekonomi ASEAN (MEA). Terdapat desa wisata yang tersebar di Provinsi Banten, dimana satu di antaranya berada di Desa Banyuresmi, Kabupaten Pandeglang, bernama Desa Wisata Kampung Bambu (DWKB) yang dikelola oleh masyarakat desa yang tergabung kedalam Kelompok Sadar Wisata (Pokdarwis). Sehubungan dengan kondisi MEA dan adanya potensi lokal tersebut, pengembangan kompetensi kerja yang sesuai dengan Standar Kualifikasi Kerja Nasional Indonesia (SKKNI) menjadi penting bagi pelaku bisnis. Bagi Pokdarwis DWKB, mereka perlu memahami kompetensi kerja, khususnya di area bidang pemasaran, sehingga kedepannya mereka mampu memasarkan desanya berdasarkan potensi alam dan potensi buatan secara terarah dan sesuai dengan unjuk kinerja pemasaran yang mereka pahami dan implementasikan. Target dari pengabdian ini yaitu Pokdarwis memahami bagaimana menyusun rencana aktivitas penjualan, melakukan pendekatan kepada calon pelanggan potensial, melaksanakan komunikasi efektif, dan mengidentifikasi elemen pemasaran DWKB. Untuk mencapai target tersebut, metode pengabdian yang dilakukan berupa pelatihan kompetensi pemasaran dengan memberikan pemahaman menyusun rencana aktivitas penjualan, melakukan pendekatan kepada calon pelanggan potensial, melaksanakan komunikasi efektif, serta mengidentifikasi elemen pemasaran DWKB. Berdasarkan simulasi uji kompetensi yang dilakukan setelah memberikan pemahaman mengenai kompetensi pemasaran, kesimpulannya adalah bahwa secara konsep, Pokdarwis belum sepenuhnya memahami dan menguasai kompetensi pemasaran dan masih terdapat beberapa kompetensi pemasaran yang perlu dijelaskan lagi seperti aspek perencanaan penjualan, komunikasi, penentuan bauran pemasaran, dan melakukan pendekatan kepada pelanggan.
\end{abstract}

Kata Kunci: Kompetensi Pemasaran, Desa Wisata, Pokdarwis

\section{PENDAHULUAN}

Kesepakatan MEA telah menyebabkan arus bebas barang, jasa, investasi, modal dan tenaga kerja. Hal ini dapat menimbulkan kekhawatiran terhadap kondisi kemampuan pasar potensial lokal dan lapangan pekerjaan masyarakat lokal dalam berkompetisi. Untuk sektor industri pariwisata, kekhawatiran ini bukan hanya dialami oleh industri pariwisata yang dijalankan oleh perusahaanperusahaan besar, namun juga pariwisata berbasis masyarakat yang tentu bisa menjadi titik kritis 
dari kondisi tersebut. Berkaitan dengan kondisi tersebut, pariwisata lokal menjadi salah satu sektor penting yang perlu diperhatikan oleh lembaga Perguruan Tinggi melalui pemberdayaan dan pengabdian masyarakat agar sektor ini mampu berdaya saing.

Dalam perkembangannya, konsep pariwisata berbasis masyarakat semakin dianggap sebagai alternatif yang lebih berkelanjutan, karena menekankan keterlibatan aktif masyarakat setempat dan kontrol mereka terhadap pengembangan pariwisata. Konsep pariwisata berbasis masyarakat (Community Based Tourism/CBT) merupakan sebuah konsep pengembangan suatu destinasi wisata melalui pemberdayaan masyarakat lokal, dimana masyarakat turut andil dalam perencanaan, pengelolaan dan penyampaian pendapat (Goodwin \& Santili, 2009). CBT adalah pariwisata yang memperhitungkan aspek keberlanjutan lingkungan, sosial dan budaya. Lebih jauh lagi, CBT merupakan alat bagi pembangunan komunitas dan konservasi lingkungan atau dengan kata lain CBT merupakan alat bagi pembangunan pariwisata berkelanjutan (Suansri, 2003).

Salah satu representasi dari pembangunan pariwisata berbasis masyarakat adalah Desa Wisata. Sebagai salah satu sinergisitas antara program pemerintah (dalam hal ini melalui Kementerian Pariwisata) dengan perguruan tinggi melalui program pemberdayaan masyarakat, maka dibutuhkan sebuah program berkesinambungan sebagai upaya efisiensi dan efektifitas program produktif dalam Pemberdayaan Masyarakat berbasis Pariwisata berkelanjutan.

\section{Gambar 1}

DWKB Sebagai Desa Binaan FEB UNTIRTA

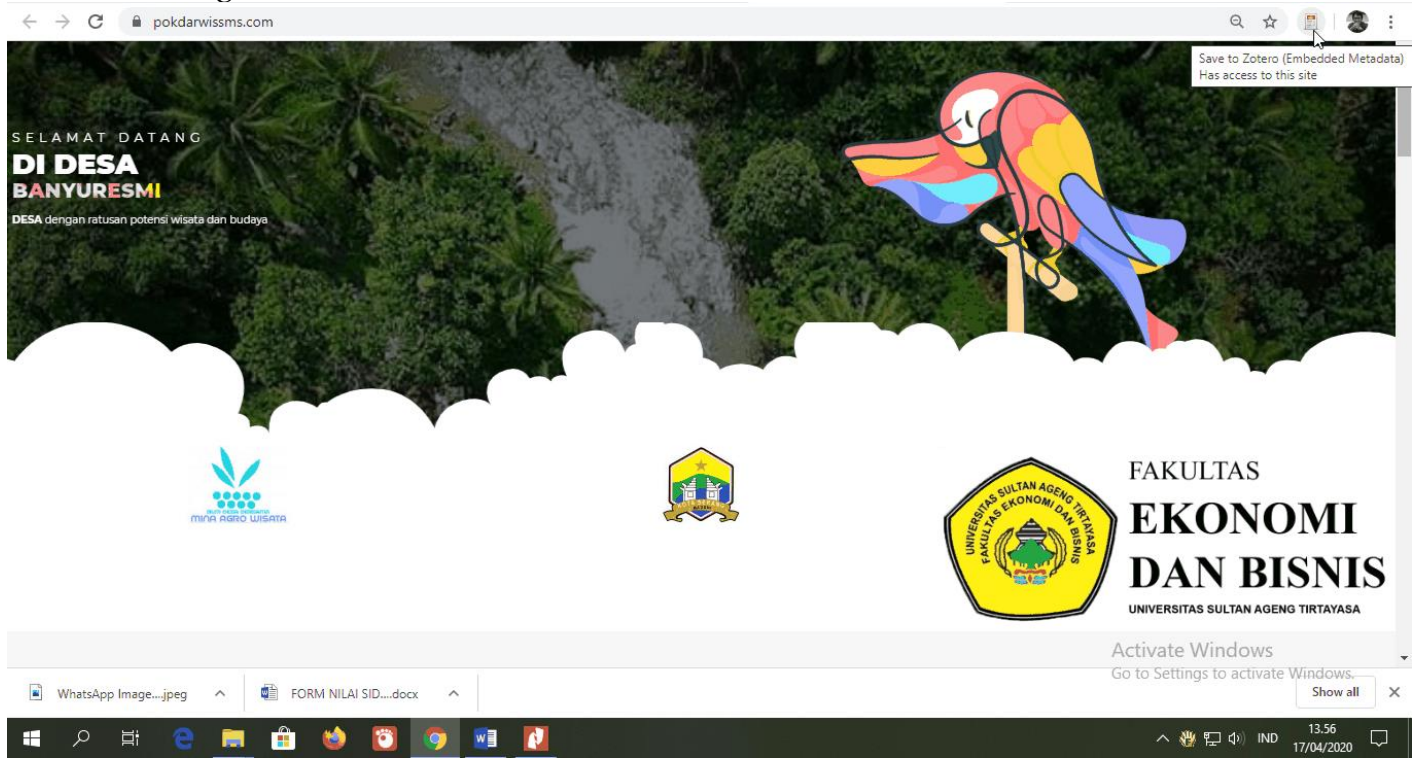

Sumber. www.pokdarwissms.com

Terdapat desa wisata yang tersebar di seluruh Indonesia, dimana satu diantaranya berada di Kabupaten Pandeglang Provinsi Banten yaitu satu desa wisata yang terletak di Desa Banyuresmi Kecamatan Jiput, bernama Desa Wisata Kampung Bambu (DWKB). Desa ini merupakan Desa Binaan Fakultas Ekonomi dan Bisnis (FEB) UNTIRTA sebagai bentuk hasil kerjasama antara Asisten Deputi Pengembangan SDM Pariwisata dan Hubungan Antar Lembaga Kementerian Pariwisata Republik Indonesia dengan Direktur Pengembangan Daerah Pulau Kecil dan Terluar Kementerian Desa, Pengembangan Daerah Terpencil, dan Transmigrasi Republik Indonesia dan Universitas Sultan Ageng Tirtayasa (Gambar 1). 


\section{Gambar 2}

\section{Fasilitas Desa Wisata Kampung Bambu}

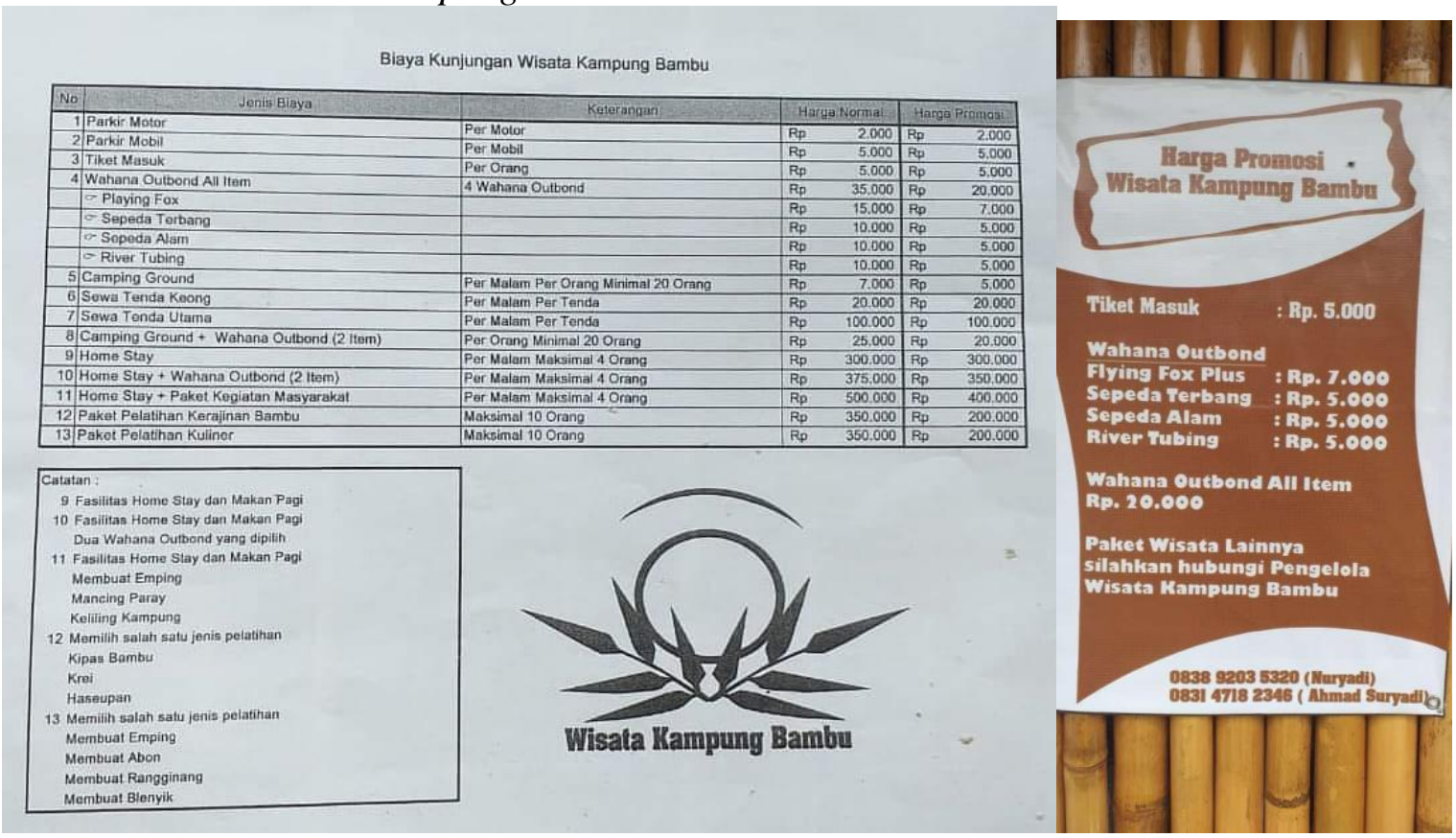

\section{Gambar 3}

\section{Fasilitas Desa Wisata Kampung Bambu}

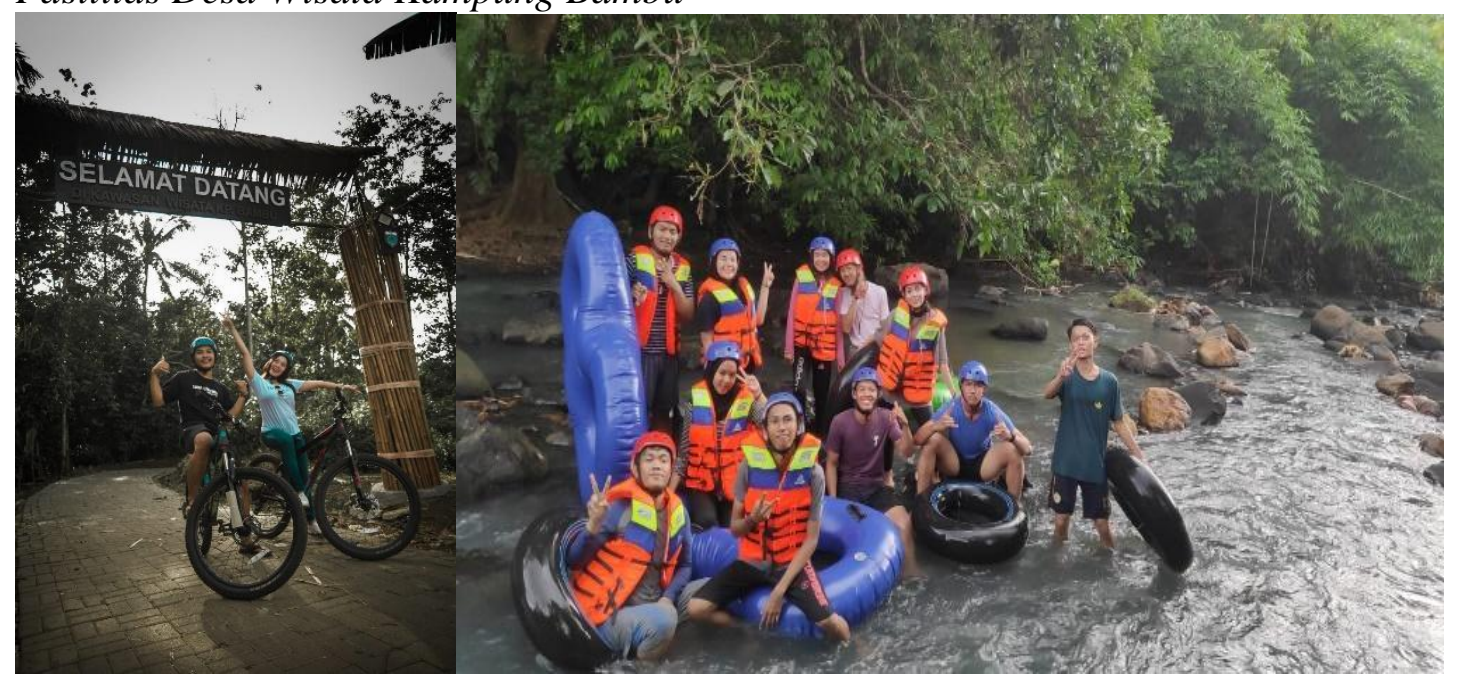

Sumber. www.pokdarwissms.com

Sejauh ini, wahana-wahana rekreasi pada DWKB dinilai belum cukup dapat menarik wisatawan lebih banyak lagi, sebagaimana yang pernah dinyatakan oleh pengelola dari unsur Pokdarwis (Gambar 2 dan Gambar 3). Menurut Oji Fahruhoji, pengelola DWKB, meski setiap pekan dikunjungi wisatawan namun belum maksimal karena jumlah wisatawan yang datang masih di bawah ratusan per pekan. Lebih jauh lagi, sejak awal tahun 2020 hingga bulan April tahun 2020 jumlah kunjungan mengalami penurunan yang drastis tiap bulannya (Tabel 1). 


\section{Tabel 1}

Jumlah Pengunjung Desa Wisata Kampung Bambu

\begin{tabular}{llc}
\hline No & Bulan & Jumlah Pengunjung \\
\hline 1 & Januari & 204 \\
\hline 2 & Februari & 108 \\
\hline 3 & Maret & 24 \\
\hline Total & & 336 \\
\hline
\end{tabular}

Berdasarkan uraian kondisi dan potensi tersebut, maka pengembangan kompetensi kerja yang sesuai dengan Standar Kualifikasi Kerja Nasional Indonesia (SKKNI) menjadi penting bagi pelaku bisnis, khususnya Pokdarwis DWKB. Hal ini bertujuan agar mereka dapat mengenali dan memahami kompetensi kerja di area bidang pemasaran, sehingga kedepannya diharapkan mereka mampu memasarkan desanya berdasarkan potensi alamiah dan buatan yang dimiliki secara terarah dan sesuai dengan unjuk kinerja pemasaran.

Standarisasi kompetensi yang dimaksud merupakan kompetensi pemasaran yang sesuai dengan Standar Kualifikasi Kerja Nasional Indonesia (SKKNI) yang merupakan instrumen standarisasi unjuk kerja warga negara Indonesia sesuai bidangnya dalam rangka menghadapi MEA. Pada akhirnya, program pengabdian masyarakat ini mencoba menggabungkan unsur akademik dibidang pemasaran dan praktek SKKNI di bidang/ area kerja pemasaran berdasarkan Keputusan Menteri Tenaga Kerja dan Transmigrasi Republik Indonesia Nomor 389 Tahun 2013, yang terdiri kompetensi rencana aktivitas penjualan, pendekatan kepada calon pelanggan potensial, komunikasi efektif, dan mengidentifikasi elemen pemasaran.

\section{Tabel 2}

Metode Pelaksanaan

\begin{tabular}{|c|c|c|}
\hline No. & Target & Metodologi Pelaksanaan \\
\hline \multirow{2}{*}{1.} & \multirow{2}{*}{$\begin{array}{l}\text { Pokdarwis mampu menyusun } \\
\text { Rencana Aktivitas Penjualan }\end{array}$} & $\begin{array}{l}\text { Memberikan pelatihan mengenai pengetahuan, keterampilan dan sikap } \\
\text { kerja yang dibutuhkan dalam menyusun rencana aktivitas penjualan }\end{array}$ \\
\hline & & $\begin{array}{l}\text { Menyelenggarakan diskusi kelompok mengenai bagaimana menyusun } \\
\text { Rencana Aktivitas Penjualan }\end{array}$ \\
\hline \multirow[t]{2}{*}{2.} & \multirow{2}{*}{$\begin{array}{l}\text { Pokdarwis mampu melakukan } \\
\text { pendekatan kepada calon } \\
\text { pelanggan potensial }\end{array}$} & $\begin{array}{l}\text { Memberikan pelatihan mengenai pengetahuan, keterampilan dan sikap } \\
\text { kerja yang dibutuhkan dalam melakukan pendekatan kepada calon } \\
\text { pelanggan potensial }\end{array}$ \\
\hline & & $\begin{array}{l}\text { Menyelenggarakan diskusi kelompok bagaimana melakukan } \\
\text { pendekatan kepada calon pelanggan potensial }\end{array}$ \\
\hline \multirow{2}{*}{3.} & \multirow{2}{*}{$\begin{array}{l}\text { Pokdarwis mampu } \\
\text { melaksanakan Komunikasi } \\
\text { Efektif }\end{array}$} & $\begin{array}{l}\text { Memberikan pelatihan mengenai pengetahuan, keterampilan dan sikap } \\
\text { kerja yang dibutuhkan dalam melaksanakan komunikasi efektif }\end{array}$ \\
\hline & & $\begin{array}{l}\text { Menyelenggarakan diskusi kelompok bagaimana melaksanakan } \\
\text { komunikasi efektif }\end{array}$ \\
\hline \multirow[t]{2}{*}{4.} & \multirow{2}{*}{$\begin{array}{l}\text { Pokdarwis mampu } \\
\text { mengidentifikasi Elemen } \\
\text { Pemasaran DWKB }\end{array}$} & $\begin{array}{l}\text { Memberikan pelatihan mengenai pengetahuan, keterampilan dan sikap } \\
\text { kerja yang dibutuhkan dalam mengidentifikasi elemen pemasaran } \\
\text { DWKB. }\end{array}$ \\
\hline & & $\begin{array}{l}\text { Menyelenggarakan diskusi kelompok bagaimana mengidentifikasi } \\
\text { elemen pemasaran DWKB }\end{array}$ \\
\hline
\end{tabular}

\section{METODE PELAKSANAAN PKM}

Pelaksanaan program pengabdian ini dilakukan dengan tiga tahapan, yaitu:

1. Persiapan. Tim melakukan survei lapangan dan menganalisis permasalahan di Desa Wisata Kampung Bambu, dan merancang serta memutuskan solusi apa yang akan diimplementasikan di Desa Wisata Kampung Bambu. Sehubungan dengan masih lemahnya pemasaran Desa 
Wisata Kampung Bambu yang disebabkan oleh masih minimnya kemampuan pemasaran para Pokdarwis yang diindikasikan dengan masih kurangnya jumlah angka kunjungan wisatawan meskipun fasilitas yang disiapkan sudah baik, maka metode pelaksanaan yang dilakukan pada program ini adalah dengan memberikan pelatihan dan pendampingan mengenai Pemasaran yang menekankan pada aspek penjualan, pendekatan pelanggan, komunikasi, dan bauran pemasaran yang dilanjutkan dengan simulasi uji kompetensi pada bidang yang dimaksud tersebut.

2. Tahap pelaksanaan. Tabel 2 merupakan tabel mengenai target dan metode pelaksanaan dari program pengabdian ini. Pada tahap pelaksanaan ini tim memberikan pelatihan dan pendampingan mengenai Pemasaran yang menekankan pada aspek penjualan, pendekatan pelanggan, komunikasi, dan bauran pemasaran yang dilanjutkan dengan simulasi uji kompetensi melalui diskusi kelompok.

3. Evaluasi. Tahapan evaluasi dilakukan dengan mengumpulkan data-data dari pokdarwis mengenai pemahaman mereka tentang materi pelatihan, dan juga menganalisis apa saja yang telah pokdarwis lakukan selama mengembangkan Desa Wisata Kampung Bambu yang berhubungan dengan kemampuan Pemasaran.

\section{HASIL DAN PEMBAHASAN}

Pada dasarnya, kegiatan pengabdian ini merupakan bentuk dari kegiatan pemberdayaan masyarakat. Sebagaimana yang diuraikan oleh Jimmu (2008) bahwa pengembangan masyarakat memiliki arti perkembangan di tingkat masyarakat. Lebih jauh lagi, pembangunan DWKB perlu mencerminkan tindakan masyarakat dan kesadaran atas identitas diri desa tersebut. Jimmu (2008) menjelaskan bahwa pengembangan masyarakat tersebut tidak selalu masalah ekonomi, teknis, maupun infrastruktur. Melalui kegiatan pengabdian ini, maka proses pengembangan DWKB dengan memberikan pelatihan oleh pihak eksternal desa (dalam hal ini tim pelaksana program pengabdian masyarakat) dengan menawarkan konsep kompetensi pemasaran kepada Pokdarwis sebagai unsur masyarakat desa yang mengelola DWKB dan juga sebagai agen pembangunan desa yang memahami karakteristik serta sistem yang berlaku di desa tersebut.

DWKB merupakan sebuah entitas bisnis masyarakat yang terlahir secara bottom up dengan segala potensi alam, inovasi dan kreatifitas masyarakat desanya. Tantangan MEA serta adanya kebijakan pemerintah terkait pentingnya Kompetensi Pemasaran merupakan arus perkembangan yang bersifat top down yang perlu untuk disikapi oleh DWKB dalam menghadapi perubahan bisnis pariwisita kedepannya, sehingga proses berkembangnya desa tersebut secara bottom up akan terus berkembang secara dinamis. Hal ini sebagaimana yang diurai oleh Shucksmith (2012) yang menyatakan bahwa pengembangan masyarakat perlu memperhatikan selisih, atau gap yang muncul karena adanya perbedaan antara perubahan yang terjadi serta adanya kekhasan lokal pada DWKB.

Dalam implementasi kegiatan ini, tantangan terbesar pengembangan kompetensi pemasaran DWKB adalah pada kapasitas atau kualifikasi peserta pelatihannya. Dari 30 orang peserta, hanya 1 (satu) orang yang memiliki latar belakang pendidikan sarjana, selebihnya berpendidikan SMA dan SMA kebawah serta belum memiliki pengalaman pekerjaan profesional di bidang pemasaran. Oleh karena itu, mengacu pada Adedokun et al. (2010), bahwa komunikasi yang efektif penting dan akan menimbulkan peran aktif dari anggota masyarakat dalam rangka pemberdayaan DWKB, maka melalui diskusi kelompok yang dilakukan setelah pemberian materi mengenai kompetensi pemasaran menjadi penting agar peserta pelatihan menerima manfaat dari kegiatan ini.

Kegiatan ini diawali dengan memberikan pelatihan kepada 30 (tiga puluh) orang Pokdarwis yang merepresentasikan pengelola DWKB, dimana di dalamnya terdapat unsur Badan Usaha Milik 
Desa (BuMDES), kepemudaan serta unsur pemerintah desa dan kemudian diakhiri dengan diskusi kelompok untuk membahas mengenai kompetensi pemasaran yang telah disampaikan dan perlu untuk ditindaklanjuti (Gambar 4). Adapun hasil dan pembahasan kegiatannya sebagai berikut:

1. Menyusun rencana aktivitas penjualan.

Pada unit kompetensi ini disampaikan 2 elemen kompetensi yang terdiri dari:

a. Melaksanakan pengelolaan waktu.

Pada kompetensi ini, Pokdarwis diharapkan mampu membuat daftar dan target penjualan berupa target jumlah pengunjung yang datang selama satu periode yang ditetapkan. Berdasarkan diskusi kelompok peserta, terungkap bahwa selama ini mereka belum pernah membuat rancangan target penjualan dalam suatu periode tertentu. Meskipun demikian mereka mampu untuk melakukannya setelah memahami penjelasan pentingnya aktifitas ini.

b. Melaksanakan pengelolaan teritori.

Dalam konteks ini, Pokdarwis perlu melakukan perluasan atau sekurang-kurangnya penetapan wilayah pasar. Sejauh ini, pendekatan ini belum sama sekali dilakukan dan terlihat sulit bagi Pokdarwis untuk melakukannya, meskipun pentingnya kompetensi ini telah dijelaskan.

\section{Gambar 4}

\section{Penyampaian Materi Kompetensi Pemasaran dan Diskusi Kelompok}

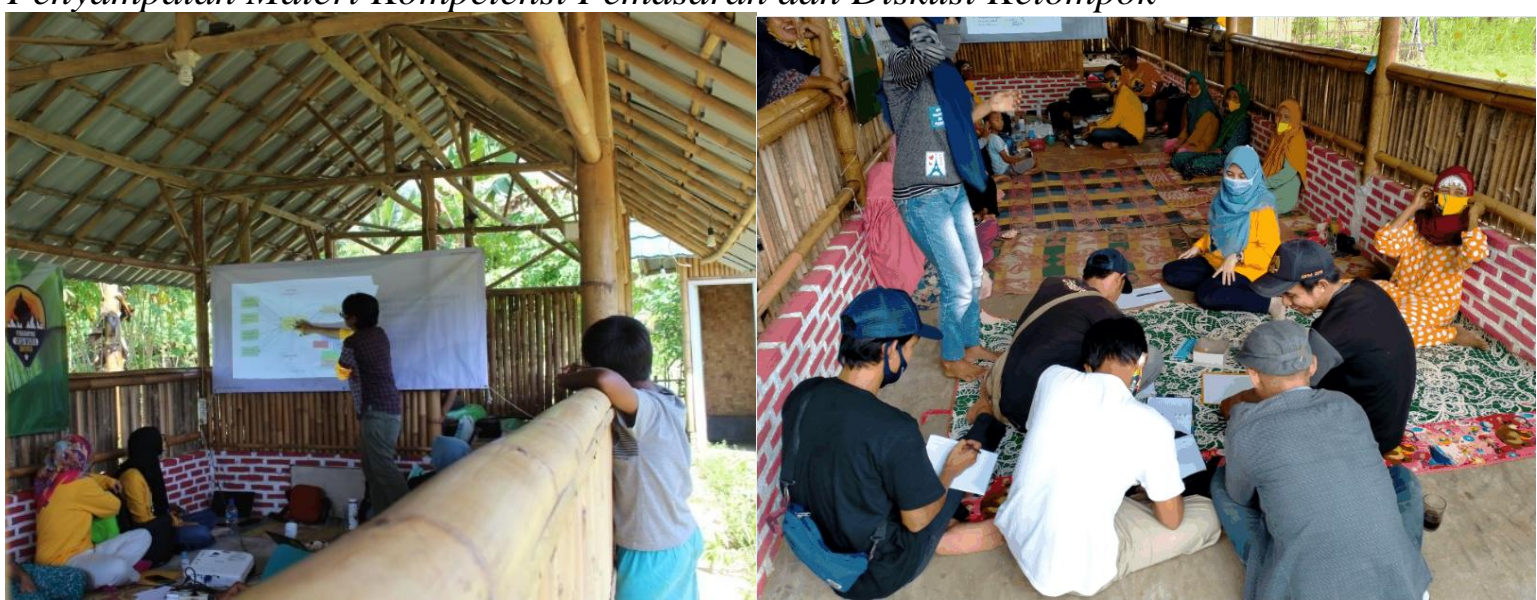

2. Melakukan pendekatan kepada calon pelanggan potensial.

Berkaitan dengan pendekatan pelanggan, maka setidaknya diperlukan 2 elemen kompetensi yang harus bisa dilakukan, yaitu:

a. Prospecting

Kompetensi ini berkaitan dengan bagaimana mendapatkan data calon pelanggan potensial. Unjuk kerjanya berupa mencari pelanggan potensial, dan memiliki data pelanggan yang lengkap, akurat dan relevan. Sejauh ini, DWKB masih cenderung wait and see, atau menunggu datangnya pelanggan. Peran Pokdarwis belum sampai pada tahapan prospecting. Namun, berdasarkan simulasi uji kompetensi, terungkap bahwa pada dasarnya mereka memiliki pelanggan potensial yang sangat mungkin untuk dipersuasi, yaitu unsur pemerintah daerah, hotel di kawasan Pandeglang, dan institusi pendidikan baik itu tingkat menengah maupun pendidikan tingkat tinggi.

b. Menghubungi calon pelanggan potensial.

Tidak berbeda jauh dengan elemen kompetensi sebelumnya, elemen ini belum pernah dilakukan sebelumnya. Namun melalui diskusi kelompok peserta, terungkap bahwa ketika rincian pelanggan potensial sudah disusun, maka aktivitas ini dapat ditindaklanjuti.

3. Melaksanakan komunikasi efektif. 
Kompetensi ini berkaitan dengan pengetahuan, keterampilan dan sikap kerja yang dibutuhkan dalam melaksanakan komunikasi efektif. Agar dapat diterapkan, maka setidaknya Pokdarwis perlu menguasai kompetensi berikut:

a. Mengidentifikasi model gaya komunikasi seorang pelanggan.

Pada kompetensi ini, Pokdarwis harus mampu mengidentifikasi gaya komunikasi pelanggan dan menguasai teknik dalam menghadapi pelanggan dengan gaya komunikasi yang berbeda-beda. Sejauh ini, mereka belum memahami bagaimana gaya berkomunikasi yang baik dengan konsumen yang berbeda-beda, yaitu dengan pendekatan yang datar, cenderung hanya informal dan kurang mengedepankan bahasa indonesia yang baik dan benar dalam memberikan penjelasan kepada konsumen. Meskipun demikian, berdasarkan hasil diskusi kelompok peserta, pada dasarnya mereka tidak memiliki kendala dalam menerapkan gaya komunikasi yang efektif. Kendala utama hanya belum memahami pentingnya gaya komunikasi dalam menghadapi konsumen yang beraneka ragam.

b. Melaksanakan komunikasi langsung menggunakan bahasa verbal dan non verbal.

Dalam kompetensi ini, setidaknya Pokdarwis harus mampu mempertimbangkan memilih kata-kata saat berkomunikasi, mengendalikan bahasa tubuh dan ekspresi wajah, menata penampilan profesional, dan melaksanakan komunikasi dengan baik antara pelanggan dan staf. Berkaitan dengan kompetensi sebelumnya, terungkap bahwa penggunaan bahasa informal dominan dilakukan oleh Pokdarwis. Selain itu, berkaitan dengan bahasa tubuh, sejauh ini Pokdarwis belum terbiasa. Hal ini terungkap berdasarkan simulasi uji kompetensi, meski demikian mereka menganggap perlu untuk melakukan pengembangan diri berkaitan dengan komunikasi verbal dan bahasa tubuh.

4. Mengidentifikasi elemen bauran pemasaran.

Kompetensi ini merupakan yang terpanjang dan terkompleks diantara 3 kompetensi lainnya yang harus dikuasai oleh Pokdarwis. Setidaknya Pokdarwis harus mampu menguasai unsur kompetensi berikut ini:

a. Mengidentifikasi elemen strategi pemasaran desa wisata.

Pada kompetensi ini, setidaknya Pokdarwis harus mampu menjelaskan definisi segmentasi, targeting, dan positioning secara pemahaman dan praktek dalam memasarkan desa wisata. Diawali dari merumuskan segmentasi perusahaan dalam hal ini pengunjung yang diharapkan sebagai konsumen. Kemudian target segmen diidentifikasi berdasarkan segmentasi yang dilakukan sebelumnya, sehingga desa wisata mampu menentukan positioning nya di dunia Pariwisata lokal.

Berdasarkan simulasi uji kompetensi, terungkap bahwa selama ini Desa Wisata belum secara spesifik melakukan segmentasi konsumen, sehingga mendefinisikan 'siapa' konsumen desa wisata masih belum bisa dilakukan. Namun, setelah diberikan pemahaman tahapan segmentasi dan targeting konsumen, mereka merumuskan bahwa konsumen mereka adalah 'grup', yaitu pengunjung dalam jumlah besar, seperti keluarga, rombongan kantor, kegiatan sekolah, kegiatan mahasiswa, dan lain-lain. Dengan kata lain, konsumennya bukan individu.

b. Mengidentifikasi elemen taktik pemasaran desa wisata.

Pada kompetensi ini, setidaknya Pokdarwis harus mampu merumuskan keunggulan desa wisata yang membedakannya dengan tempat wisata lainnya. Tahapannya dimulai dari merumuskan definisi diferensiasi, bauran pemasaran dan penjualan. Sejauh ini, bisa dikatakan, kondisi alam merupakan keunggulan yang dimiliki oleh DWKB. Namun, hal ini belum dirumuskan secara solid dan dipasarkan menjadi trademark desa tersebut. Oleh karena itu tahapan menggali potensi alam menjadi penting. Berkaitan dengan bauran pemasaran, sejauh ini DWKB lebih dominan baru menggunakan konsep Promosi saja melalui media sosial secara sederhana. 
Secara umum, selama ini kerangka konsep diferensiasi keunggulan DWKB belum mampu dirumuskan baik secara infrastruktur, konten, maupun konteks produknya. Meskipun, fasilitas aktivitas-aktivitas alam seperti arung jeram, outbound, hiking trail, dan sejenisnya sebetulnya sudah ada di desa tersebut.

c. Mengidentifikasi elemen value pemasaran desa wisata.

Pada kompetensi ini, setidaknya Pokdarwis diharapkan mampu menjelaskan definisi merek, layanan, dan proses yang diberikan kepada pengunjung. Selama ini, DWKB secara merek belum dirumuskan secara jelas dan menarik. Kemudian, berdasarkan simulasi uji kompetensi, terungkap adanya upaya peningkatan kompetensi dalam menjabarkan secara jelas konsep layanan apa yang dapat diberikan kepada pengunjung.

Secara spesifik, kompetensi ini juga memerlukan kemampuan dalam menerapkan dimensi kualitas pelayanan. Secara konsep, Pokdarwis belum memahaminya, namun secara praktek, mereka telah berupaya menerapkan konsep service quality meskipun masih terdapat unsur yang masih perlu ditingkatkan kembali yaitu keamanan dan keselamatan.

\section{KESIMPULAN}

Dengan mengacu pada SKKNI, pada dasarnya kemampuan Pokdarwis dalam memasarkan DWKB masih perlu ditingkatkan. Meskipun demikian, berdasarkan simulasi uji kompetensi yang dilakukan setelah memberikan pemahaman mengenai kompetensi pemasaran, maka diperoleh kesimpulan berikut ini:

1. Secara konsep, Pokdarwis belum sepenuhnya memahami dan menguasai kompetensi pemasaran. Meskipun demikian, terdapat perubahan dalam berpikir serta terdapat diantara aktifitasnya yang ternyata sudah menjalankannya secara sederhana, seperti promosi, penetapan harga, dan pendefinisian produk yang ditawarkan.

2. Masih terdapat beberapa kompetensi pemasaran yang perlu dijelaskan lagi, baik itu dari aspek perencanaan penjualan, komunikasi, penentuan bauran pemasaran, dan melakukan pendekatan kepada pelanggan.

\section{Ucapan Terima Kasih (Acknowledgement)}

Ucapan terimakasih disampaikan kepada pihak-pihak yang mendukung dan terlibat dalam kegiatan PKM ini, yaitu:

1. Fakultas Ekonomi dan Bisnis Universitas Sultan Ageng Tirtayasa yang telah memberikan hibah pengabdian pada masyarakat tahun 2020 kepada tim pelaksana.

2. Tim pendamping desa wisata FEB UNTIRTA yang telah membantu persiapan teknis pelaksanaan kegiatan.

3. Pokdarwis, BUMDES, dan Kepala Desa Banyuresmi yang telah berpartisipasi secara bersama-sama dan berkenan untuk menerima tim pelaksana dalam pelaksanaan kegiatan.

\section{REFERENSI}

Adedokun, M. O., Adeyemo, C. W., \& Olorunsula, E. O. (2010). The impact of communication on community development. Journal of Communication, 1(2), 101-105. https://doi.org/10.1080/0976691x.2010.11884775

Jimu, I. M. (2008). Community development: A cross-examination of theory and practice using experiences in Rural Malawi. Africa Development, 33(2), 23-35. http://dx.doi.org/10.4314/ad.v33i2.57277

Goodwin, H., \& Santilli, R. (2009). Community based tourism: A success?. ICRT Occasional Paper 11. Gtz.

Keputusan Menteri Tenaga Kerja dan Transmigrasi Republik Indonesia Nomor 389 Tahun 2013 Tentang Penetapan Standar Kompetensi Kerja Nasional Indonesia Kategori Jasa Profesional, 
Ilmiah dan Teknis, Golongan Pokok Kegiatan Kantor Pusat dan Konsultasi Manajemen, Golongan Konsultasi Manajemen, Sub Golongan Konsultasi Manajemen Area Kerja Pemasaran. (2013). Indonesia. https://jdih.kemnaker.go.id/data_puu/SKKNI\%202013-389.pdf Shucksmith, M. (2012). Future direction in dural development. Carnegie UK Trust.

Suansri, P. (2003). Community based tourism handbook. Responsible Ecological Social TourREST. 